\title{
The Travel Writer as Cultural Icon and Literary Predecessor: Negotiating the African Legacy of S. K. Pottekkat
}

\author{
Meera B. \\ Assistant Professor, Department of English, Amrita School of Arts and Sciences, Amrita \\ Viswa Vidyapeetham, Kochi Campus. ORCID: oooo-0o02-8395-9051. \\ Email:meerab8526@gmail.com.
}

\begin{abstract}
S. K. Pottekkat has been the most influential travel writer in Malayalam for many generations of Malayali readers. His travels in Africa in the year 1949-50, recorded in five travelogues beginning with the midtwentieth century Kappirikalude Nattil, have inspired generations of Malayalis to follow suit and pursue the African dream. This is much more pronounced in the case of well-known Malayali writers whose attempts to write about Africa have inevitably involved a "writing back" to Pottekkat. In this paper, I analyze the African travelogues of two such writers - Tatapuram Sukumaran's African Poorvadeshangalil in 1986 about his trip to Tanzania and Paul Zacharia's Oru African Yatra(2005) about his travels from South Africa to Egypt in 200o. Sukumaran is hailed by the Malayali diaspora as the first Malayali writer after Pottekkat to visit the country while the writer-journalist Zacharia is on a self-proclaimed mission "to seek out the present-day form of that Africa which Pottekkat found 54 years ago". Unsurprisingly, the major part of his journeys is undertaken through the well-trodden paths taken by Pottekkat who himself was inspired by the celebrated travel accounts of Livingstone and Stanley. In this paper, I intend to explore how these two writers writing about Africa in the humungous literary shadow of Pottekkat negotiate his African legacy in the Malayali literary imaginary. How far does the "anxiety of influence" of Pottekkat's picture of Africa, which was colonial and Eurocentric, impinge on these writers who are trying to represent postcolonial Africa for a different audience in a different time? What are the strategies they adopt to create a distinct voice? These questions, in turn, lead to larger questions about how each tenderfoot traveller's gaze is mediated by the verisimilar lens of existing discourses as well as by the horizon of expectations of his/her reading public brought up on these canonical narratives.
\end{abstract}

Keywords: Pottekkat, Sukumaran, Zacharia, Malayali travel writing, Africa, anxiety of influence

S. K. Pottekkat is widely regarded as the first 'proper' travel writer in Malayalam, sometimes called "Malayalam's John Gunther" as his journeys were said to be motivated by 'wanderlust' unlike many others before him. In 1949, just two years after India won her independence, Pottekkat travelled to East Africa in search of what he termed the rapidly declining figure of the "natural man." His African sojourn which marked the start of his world tour lasted a period of nine months and was accomplished in cheap public and private transport and frequent travels on foot. He published his account of these travels in five travelogues, the first one being Kappirikalude Nattil or the land of the Kappiris, a pejorative term used to denote black Africans. At a time when travelling outside India was as much about discovering new parts of the world as about constructing the Indian travelling subject, the trip served two functions. It was fuelled by an inherited colonial desire to discover and subject "the last man shaped entirely by nature" to the

(C) AesthetixMS 2020. This Open Access article is published under a Creative Commons Attribution Non-Commercial 4.o International License (http://creativecommons.org/licenses/by-nc/4.o/), which permits non-commercial re-use, distribution, and reproduction in any medium, provided the original work is properly cited. For citation use the DOI. For commercial re-use, please contact editor@rupkatha.com. 
civilized "gaze" of the traveller and by extension, that of his native audience struggling to respond to the sweeping challenges of modernity and industrialization. The travelogue also participated in debates about the construction of the good Indian citizen at a time when the question of the future of the Indian diaspora in East Africa was being debated in the backdrop of rising ethnonationalist movements in East Africa.

Pottekkat travelled to East Africa at a time when the African continent was steeped in myth and mystery for the Malayalis. Through his accounts, he presented a picture of Africa that has influenced generations of Malayali readers and travellers. It was through Pottekkat's eyes that the average Malayali reader saw Africa for the first time. Pottekkat's African travelogues also introduced certain tropes of representing Africa to Malayali readers which were tirelessly replicated for many decades in later travelogues. They became the benchmark for travel writers in Malayalam to follow. His legacy as a travel writer has been summed up by the writer and critic Zacharia who followed Pottekkat's trajectory to Africa fifty-two years later in his interview "Mahasanchariyude Pathayil":

In my opinion, what S. K. did was first hand reporting about what was outside Kerala and India. After Varthamanapusthakam, what ThomaKathanar wrote after visiting Rome in the 18th century, and subsequently K. P. Kesava Menon's books...he is the first person to have reported to Malayalis about what was outside. It is not enough to term this revolutionary or pathbreaking. In charming literary language, he told the Malayalis there is a place called Africa, there is a place called Bali Island, these are the things worth seeing in Switzerland etc. This is a milestone. When we talk about the history of our modernity, S. K. cannot be reduced to a mere writer or travel writer. (p.15) (Meera p. 20)

The success of Pottekkat's travelogues led to a number of travelogues getting published serially in this magazine in the 1950s, partially guided by other factors. One was a widespread interest in the "sensational" and "exotic" - the "wild" Africa of dense jungles, cannibals, "primitive" tribes, "lurid" customs and "obscene" dances. The other was a more highbrow interest in the anti-colonial struggles that were raging in the African countries especially in the 1950 os and 6os, when there were also attempts to topple the new native governments. By the 1980 , though when Tatapuram Sukumaran visits Tanzania, the African continent had largely receded in Malayali popular memory.

Sukumaran's 1986 African Poorvadeshangalil[In the Eastern Lands of Africa] narrates his experiences of visiting Tanzania in East Africa along with his wife, about thirty-seven years after Pottekkat visited the country. Despite the passage of thirty-seven years, Sukumaran's attempt in the preface of his African travelogue African Poorvadeshangalil is to present an Africa that mostly corresponds to the one that has been familiar to Malayali readers through Pottekkat's African travelogues - a land of darkness and barbarity, frozen in time and unable to move forward. Pottekkat looms as an influential figure right from the preface where Sukumaran mentions how the latter had travelled to Africa to see man in his natural state and how his own experiences gave him a similar impression. According to Meera, Sukumaran (1987) writes:

I saw blood drinkers in the jungles where cannibals used to reside once. The Maasai tribe drinks the blood of young bulls even today. Such a scene of blood drinking staged in the middle of the jungle keeps tormenting the mind even now. Like this, the sights that I witnessed in the Eastern lands of Africa were all rare sights.... A kind of horror which I never experienced while visiting America or Europe envelops Africa. Africa is still in darkness. This book is just a lamp-light into that darkness. I am gratified if the readers get a "little light" (p. 6-7).(p. 163) 
Despite such claims, when we get to the actual events narrated in the travelogue, there aren't many that correspond to what Sukumaran promises. As if to compensate, a paranoiac sense of acute danger is evoked by the writer at times, though the danger never comes to pass and is more a perceived threat than an actual one. The bloodcurdling episode Sukumaran promises in the "Preface" turns out not to be part of any dangerous escapade, but rather a staged performance he pays to witness of a Maasai ritual in a Maasai hut. The sight of the Maasais armed with bows, arrows and spears is invoked to give the scene a sense of imminent danger. As Sukumaran watches, the Maasai man, almost nonchalantly, makes a wound in the bull's jugular with an arrow, collects the streaming blood and drinks. Contrary to Sukumaran's expectations, the bull does not fall dead due to blood loss since it is revived by the old man who applies some medicine to its wound.

What Sukumaran thus unwittingly presents is a picture of an African tribal ritual presented for the pleasure of the tourist. There is no sense of danger involved for the tourist who watches this scene. From other instances in the text, it is clear that Sukumaran is aware of how the tribals are making a quick buck this way by selling their culture and their rituals. Thus what Sukumaran presents as an instance of the Maasais still living in their past and practising their barbaric rituals is a new age ethnic tourism of the African tribes into which they have been coopted. However, he cannot speak openly about this fact because it would contradict the established wild and barbaric textual Africa for his audience.

Tribal tourism is what Sukumaran encounters again when a "Gomba" dance is held in his honour by Kalamandalam, the Malayali organization in Tanzania. One of the interesting accounts in Pottekkat's travelogues is his incessant attempts to get to see this native tribal dance which had been banned by the European government under charges of obscenity. He travels to a lot of places hoping to see the Goma and it is after many trials and errors that he is able to watch and report on the dance which he does in explicitly voyeuristic terms. Sukumaran too wants to satiate the curiosity of his native audience, but by now the dance has become part of the regular tourist performances put up by Malayali organizations, largely divorced from its primitive past and toned down for an urban audience. Yet Sukumaran tries to primitivize the dance claiming that though performed in the middle of the city, it aroused in him feelings of being in the middle of the jungle. The musical instruments are described as primitive, the music and dance as terrifying and even the beats of the drums are said to be accompanied by raucous laughter that sends chills down the spine of the viewers. At the same time, the voyeuristic gaze that Pottekkat used to level at African women is also levelled by Sukumaran in his description of the way the bodies and buttocks of the female dancers move to the beats.

Sukumaran's first-hand accounts of Tanzanian dance forms being limited, he takes recourse to quoting "a traveller" on the "birth dance" of the Nsenga tribe. Interestingly, though the traveller is not mentioned by name, the quote he has used is from Pottekkat. What is ironic is that the Nsenga tribe, whose birth dance Sukumaran quotes at such length, is not a tribe native to Tanzania, the African country he is describing. Rather, they are native to Zambia and Mozambique, countries Pottekkat had been to.

The careless plagiarism also points to a lack of first-hand experience which the writer doesn't want to acknowledge. Sukumaran does not get to travel through the length and breadth of Tanzania. He visits certain national parks, markets and mostly Malayali/Indian homes. As such, his first-hand experience of the country is limited. Consequently, he relies a lot on second-hand accounts to make up his assessment of the country. These are either received impressions of the Indian diaspora there who look down upon the Black Africans or an overarching image of Africa 
that has been passed down to him through texts on Africa, especially Pottekkat's highly influential African travelogues.

However, it cannot be said that Sukumaran doesn't have experiences that challenge established ways of seeing. He reflects on how the barbaric depravity associated with Tanzanian history has been written largely by the colonizers and is being re-written in post-independent Tanzania, and does notice certain changes in Tanzanian society since Pottekkat's time. But Sukumaran remains unwilling to challenge Pottekkat's dominant discourse on Africa in any manner. The textual Africa finally proves too strong an influence to be overcome, even if certain instances show the nascent possibilities of what could have emerged as a counter discourse. Sukumaran's encounters with the young African poet Semambo and the Tanzanian stow away Bisiya show the enlightening possibilities that can emerge out of first-hand interactions. He treats them and speaks of them as people he felt respect for, not as representatives of "the primitives" he generalizes about. But it is the textual Africa constituted by second hand accounts that finally decides how he ought to represent Africa than the lived reality he encounters.

In the final reckoning, the "horizon of expectations" of Sukumaran's audience who would expect his account to have the same images of Africa circulated by Pottekkat determines the way he represents Africa. It may be a case of "anxiety of influence" as well, as Sukumaran, who was welcomed by the Malayali organization in Tanzania as just the second Malayali writer to travel to Africa, struggles to live up to the most enduring image of Africa in Malayali minds created by Pottekkat. This can account for the tension one finds in the travelogue between the Africa Sukumaran expects to find, the one which he promises his readers, and the one which he finds which is closer to the "self" than the "other". Hence the constant need to re-affirm the same old stereotypes which set straight the blurred boundaries between the "self" and the "other".

A travel writer who is able to create a much more empathetic counter discourse while trying to come to terms with Pottekkat's African legacy is the writer-critic Paul Zacharia in his Oru African Yatra(An African Journey). This travelogue records Zacharia's attempts in 2000-2001 to follow the same trajectory that Pottekkat took fifty-two years ago in an attempt to find out what came of the Africa Pottekkat "discovered" back then. Zacharia modifies Pottekkat's East African trajectory by adding South Africa to it. This travelogue was also serialized by Mathrubhumi Azchappathippu, the publishing house that had serialized Pottekkat's travelogues, before its publication as a book in 2005. It is also the most extensive African travelogue in Malayalam as it covers eight countries, two from Southern Africa and six from Eastern Africa. Zacharia also made another trip to Tanzania in 2007 which formed the basis for his African travelogue AgniparvatangaludeTazhvarayil(In the Valley of the Volcanoes) in 2009.

Pottekkat emerges as a strong presence right from the preface titled "To Pottekkat's Africa”. It not only places Zacharia's journey to Africa in context, taking us back to Pottekkat's journey fifty-two years ago, but also self-reflexively discusses the politics of representation it undertakes with regard to Africa. Zacharia discusses the importance of Pottekkat's travel writing in the time in which he was writing. Pottekkat, he says, was perhaps the first Indian writer to treat travel as an art. It was in the same era when world classics started flowing into Kerala in translation that S. K. entered the scene with his eye-witness accounts from far off corners of the world. He is of the view that even today when Africa has become the favourite destination of tourists all over the world, Indians travelling there as tourists are rare. While there were Malayalis in Africa even during S. K's time and there are many settled there even in the present day, it is no wonder that in the midst of life's exigencies, they are unable to make such long trips and write about them. All these highlight Pottekkat's importance to Malayalis as a travel writer. 
Zacharia narrates growing up reading Pottekkat's African travelogues in the countryside, "The Africa which S. K. drew for my parents, farmers and readers from the countryside, to dream about later became my secret desire" (p.14). As a result of this influence, his African journey was planned with a clear purpose right from the start. It was "to seek the present-day form of that Africa which Pottekkat found 52 years ago" (p.15). As a result, the major part of his journeys was undertaken through the paths Pottekkat had traversed (p.15).Thus Zacharia's narrative is of re-tracing a literary history through his travel writing.

However, there is a stark difference in the way Zacharia approaches Africa from the way Pottekkat approached it fifty-two years ago. Though he was travelling from India which had made a decisive break from its colonial past two years prior to his travel, more than any postcolonial interventions, what stands out in Pottekkat's views on Africa are the influences of colonial history, orientalist frameworks and a colonial subjecthood. While acknowledging his indebtedness to the Western writers he had read who had helped him in imagining Africa, Pottekkat was largely unaware of how they had also provided him with a lens to view Africa. On the other hand, Zacharia, writing fifty two years later in the aftermath of the postcolonial turn in cultural discourse, is aware of the constructedness of Africa from the very beginning. He acknowledges that his lens is textual. As he notes, "A mysterious portrait, fusing the memories of the wonderland created by S. K.'s pen with an assortment of the very many African reflections received thereafter, is the map that has been struck in my brain" (p. 15). He goes on to delineate what these reflections are. They comprise such varied things as the Tarzan comics, images from African movies and wildlife channels featuring Africa, the discourse of Western travel books and the National Geographic magazine, literary works such as Hemingway's "The Snows of Kilimanjaro" and the benumbing media portraits of civil wars, massacres and famines. The words he uses "mysterious portrait", "wonderland" "reflections" all show how this map in his brain is more fictional than factual, more second-hand than original. It has been created by his reading of disparate genres-romantic novels, adventurous travelogues, popular comics, chilling news reports as well as by his exposure to Hollywood movies which have the barbaric Africa as their setting along with wildlife channels which treat Africa as a continent of animals rather than of people.

Zacharia goes on to delineate the political, social and intellectual developments that have occurred in Africa from Pottekkat's time when colonial rule was at its peak. The African map of Pottekkat's time has been re-drawn and great political developments have taken place in Uganda, Mozambique and Sudan after independence. Zacharia then brings up the most well-known images about Africa circulated by Pottekkat's pen and tries to describe "their present-day form" (p.15). The sundry paths through which S. K. was tossed about in narrow goods lorries have given place to the most modern highways which cannot be seen in India even today. "Modernity" is the biggest change he notes. If inaccessibility was the major aspect of African paths in Pottekkat's time evident in him having to use goods lorries at times, today, they have become not just accessible, but are equipped with the most modern facilities, facilities he writes that have not yet reached India.

Another enduring image Pottekkat helped circulate about Africa especially through his photographs was that of "the half-naked African women with the big breasts and the grand buttocks" who Zacharia writes "today are trying to fit their overflowing bodies into the most modern clothes" (p. 16). Pottekkat had fetishized the African women through his words and photographs, reducing them to mere body parts. Despite interrogating the other images about Africa, Zacharia uncritically re-presents this image merely noting that they are trying to fit these 
"overflowing parts into the most modern clothes" (p. 16). In both the descriptions, one can see how the women are objectified.

Another aspect of Africa that the Malayali audience of Pottekkat's time associated strongly with the continent, especially because of their description in Pottekkat's travelogues, was the deadly epidemics that led to the deaths of millions of Africans. Zacharia (2005) writes that it is the AIDS epidemic and the civil wars that cause massacres these days. "When Pottekkat was discovering Africa, if it were the traditional epidemics which were killing off Africans, today the massacre is done by AIDS" (p.16).

Zacharia transposes the image of AIDS and civil wars on top of the image of the deadly epidemics Pottekkat had circulated. It is worth noting that the association of Africa with danger remains the same in Zacharia's words as well though the agents may have changed from Pottekkat's time. Ironically, Zacharia who is conscious about the connotations of the word "discovery" in relation to Europe discovering its next door neighbour Africa uses it casually in association with Pottekkat's travels to Africa. This is a common thread in this travelogue. He deconstructs the Western myth of the Dark Continent by saying that Africa is full of light, more than many places in Europe. But while critiquing Western stereotypes about Africa, Zacharia shies away from directly critiquing Pottekkat's representation of Africa which follows the same discursive framework.

Zacharia, in his travelogue, invokes images of Africa that Pottekkat helped circulate as the primary images of the continent. For instance, Zacharia quotes the oft-quoted passage in KappirikaludeNattil where Pottekkat refers to his first view of Africa and of the giant Kappiri at the Mombasa port. Similarly, Zacharia points out that the words Negro and Kappiri used by Pottekkat were terms which were the products of the colonial period in which Pottekkat encountered Africa. He is aware of the derogatory nature of these terms and avoids using them in his travelogue, but contends that those were the only terms available at that time to describe the African people. He further states that though he had seen blacks in India, his own association with blacks as a race happened in America. For Pottekkat, the black man was an unseen other until he saw him at the Mombasa port.

Changing his initial plan of starting his tour from East Africa, Zacharia adds Southern Africa to his itinerary. Despite being aware of the fact that Africa is not a monolith as emphasize it in his preface, Zacharia treats it as more or less a monolith in his instinctual responses to it, juxtaposed as they are with the cultural memory of Pottekkat's iconic encounter. As his plane nears Johannesburg, Zacharia (2005) greedily looks down "at Africa" and remembers the traveller who had sown the seeds of that greed in his heart (p. 22). "52 years ago, it was not such a flying man who first saw Africa. The sea, the land and the ship were its stage. It was not from the Atlantic Ocean in the West, but from the Indian Ocean in the East that S. K. Pottekkat reached Africa's shores" (p.22).

That Pottekkat was looking at East Africa while Zacharia is looking at South Africa does not seem to matter to him as he redraws the African sketch Pottekkat had drawn more than half a century ago. The role that the textual Africa the traveller is familiar with, through his reading, plays in his representation of his first glimpse of the African continent is worth noting. For Pottekkat, it was the Western discourse created by Stanley, Livingstone and Speke that determined the lens through which he saw the Kappiri. For Zacharia too, his first glimpse of Africa is mediated through his knowledge of the textual Africa Pottekkat drew for him. Zacharia's 
first glimpse of Africa is thus at once a view and a re-view. It contains both his impressions and the impressions he has derived through the lens of Pottekkat. Zacharia even visits places iconized by Pottekkat in his travelogues. Just like Pottekkat who tried to locate the Africa featured in Livingstone's journal, Zacharia too tries to locate the places in Pottekkat's descriptions and photographs and is excited to encounter places which retain the same appearance.

If Pottekkat's portrayal of his representative encounter with the black African, that of the giant Kappiri looking "awestruck" at his ship on the Mombasa port, fit in perfectly well with the existing colonial Africanist discourse, Zacharia's portrayal of his representative encounter with the black African is far more subversive. He invites the readers to laugh at him by recounting how he darted off to another path at the Johannesburg airport when he saw a black African walking towards him swinging his arms. It was only later, he confesses, that he came to know that the Africans often walk moving their bodies like this. Thus he says he remained true to the cowardly reputation Malayali intellectuals have among the common people. Though he does not mention it, his instinctive reaction might have been fuelled by the warnings he had received about the city being a hotbed of crime. However, it also points to how the black African was still a half-known "other" to him despite knowing about their history and to a lesser extent culture because of the absence of personal interactions. Yet, what his representation of the encounter does is to highlight the subjectivity of impressions. Pottekkat had ascribed stupidity to the black African based on a first encounter without any acknowledgement or even awareness of the subjectivity of his impressions. Zacharia, on the other hand, returns the gaze to himself. It is not the African who is aggressive; rather it is Zacharia who is cowardly in mistaking a cultural code as threat. It is also perhaps an ironic contrast that while Pottekkat had much to theorize on the stasis of African civilization based on the single image of the stationary black man, Zacharia's representative image is of an African man whose movement itself is interpreted as threatening.

In Pottekkat's account, the African was just stationary, a mere recipient of his "imperial" gaze. Pottekkat's recreation of the scene had all the markings of the "master of all I can see" trope described in Pratt's Imperial Eyes where the panoramic view represents "a fantasy of dominance" in which "in the physical act of describing the landscape, the writer is also mastering it" (Cited in Mills 78). On the other hand, the power hierarchy has turned upside down with the black African considered as not just capable of returning the gaze, but also perceived as an intimidating participant in the encounter.

What this passage also does is set the tone for Zacharia's self-representation in the travelogue as the self-deprecating traveller. Unlike Pottekkat, Zacharia sets himself up as a cowardly traveller who is not audacious like Pottekkat or other well-known Western travellers. It might be Zacharia's way of overcoming the anxiety of influence exerted by a canonical writer like Pottekkat. It may also be a move to make himself more acceptable to his Malayali audience as he sets out retracing Pottekkat's trajectory and indirectly challenges some of his assumptions and representations.

Zacharia's strategies of representing difference are different from that of Pottekkat. Sabitha T.P. quotes an episode where Pottekkat mentions getting offended by African smells:

What annoyed me most often during my African bus-journeys was the bad smell emanating from the bodies of Negroes. The bad odour coming from the hair of Negro women was of a different kind...their body odour was like rotten meat and the smell of their hair was like rotten vegetables. They never take baths. (Simhabhoomi 129) (p 143) 
As Sabitha goes on to note, "all sensory perceptions are filtered through a paradigm of powerrelations where the experiencing subject is the judge and the blacks are the offenders in a civil(ized) society" (p.143). Mary Douglas (as cited in Mills p. 90) has also demonstrated how "the assigning of dirtiness to the other nation was a common way of separating the coloniser from the colonized" in colonial discourse. Pottekkat had followed the same colonial strategy to show his and by extension the Indian's superiority to the black African.

On the other hand, while Zacharia goes through the same experience of getting exposed to "different" smells, a comparative framework helps him put things in perspective. "Inhaling the distinct odour of African bodies, I thought: The African who gets into a bus in Kerala and inhales the distinct odour of Malayalis must be feeling amazed in the same way" (p. 210). Zacharia also notes the odour as unfamiliar like the other Malayali travellers before him. However, the experiencing subject does not become the judge or the African the "offender in a civil(ized) society" as Sabitha T.P. notes with reference to Pottekkat (p. 143). The difference is mediated by reversing the self-other binary in the African bus.

Unlike Pottekkat, what Zacharia also does is divorce his sensory perceptions from the power relations that define them. Zacharia is not the civilized and clean being in a bus of uncivilized and dirty Africans. Rather, he becomes an outsider whose sensory perceptions are different from those around him which makes him note their odour as distinct. By bringing in the reciprocal case of the African's reaction to the odour of Malayali bodies, he tries to create another discourse of difference. It is worth noting that the word Zacharia uses is not "offended", rather "amazed". This is a conscious effort on the part of the writer to express his own sensory perceptions in a discourse of difference that is not mediated by hierarchical relations of power. What was defined as "abject" in Pottekkat's account is largely de-abjectified and normalized.

To conclude, Pottekkat, travelling to East Africa in 1949, Sukumaran travelling to Tanzania in 1986, Zacharia travelling to East and Southern Africa in 2000 belong to three time periods. When one compares the discourses these travellers create and sustain about Africa, one can certainly note a change in attitudes towards Africa and the Africans. In the travelogues of both Pottekkat and Sukumaran, the term Kappiri and Negro are used synonymously for the black Africans without the writer being sensitive to their associations. Zacharia, on the other careful about the identity politics associated with this term and avoids using it to refer to the black African.

These works are certainly indicative of the dominant discourses and counter discourses that were in circulation in their time. Pottekkat's travelogue is the most colonial in perspective, himself following the representative strategies of colonial works, since the black Africans in his travelogue are rarely regarded as human beings in their own right. Yet, there are also rare postcolonial moments as when he questions the truth of the white man's "discovery" of the Zambezi River. Sukumaran's travelogue while sticking to much of Pottekkat's premises and despite the obvious attempt to trace "man in his natural state" happens to reveal certain postcolonial re-readings of history. Other than the tribals who are presented as still living in the past, Sukumaran is also able to see the two black Africans he interacts with as people in contrast to Pottekkat. Zacharia's travelogue, written in the 21st century, is the most postcolonial in its intention, reflective of the age in which he was writing. He challenges the existing Western discourse on Africa wherever possible. At the same time, since he owes his interest in Africa to Pottekkat, one also notices Zacharia's hesitancy in calling out Pottekkat for helping circulate the discourse he is critical of. Yet, unlike Sukumaran, Zacharia does not become a mere imitator of 
Pottekkat. He is able to establish his identity as an African travel writer in his own right and overcome the anxiety of his influence to a large extent.

\section{Note:}

All translations from the original texts are mine.

\section{References}

Mills, S. (1993). Discourses of Difference: An Analysis of Women's Travel Writing and Colonialism. London: Routledge.

Pottekkat, S. K. (2002). Kappirikalude Nattil. Kottayam: D C Books.

Sabitha, T.P (2010). Darkness Invisible: Difference and Indifference in Pottekkat's Travelogues on Africa. Tapasam. Ed. Scaria Zacharia. 5(4), 141-152. The Association for Comparative Studies.

Sukumaram, T. (1987). African Poorvadeshangalil. National Book Stall.

Zacharia, P. (2005).Oru African Yatra. Kottayam: D C Books.

Zacharia, P. (2013)."Mahasanchariyude Vazhiye”. Interview by Mangadu Ratnakaran. Kalapoornika. pp. 1-5.

Meera, B (2017). "Histories of the Other, Geographies of the Self: Malayali Travellers in Africa - Some Postcolonial Debates”. [Unpublished Doctoral Dissertation].University of Hyderabad. 